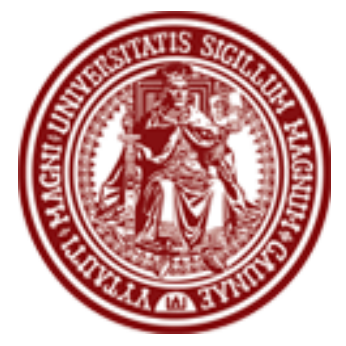

BALTIC JOURNAL OF LAW \& POLITICS

VOLUME 4, NUMBER 2 (2011)

ISSN 2029-0454

http://www.versita.com/bjlp

Cit.: Baltic Journal of Law \& Politics 4:2 (2011): 125-153

DOI: $10.2478 / \mathrm{v} 10076-011-0015-2$

\title{
CIVIL SERVICE AND CIVIL SERVANTS IN LITHUANIA: ISSUES OF REGULATION AND STATUS
}

\author{
Ernesta Visockytė \\ Doctoral Student \\ Vytautas Magnus University, Faculty of Political Sciences and Diplomacy \\ (Lithuania) \\ Contact information \\ Address: S. Daukanto str. 28, LT-44246 Kaunas, Lithuania \\ Phone: +37037327867 \\ E-mail address: e.visockyte@pmdf.vdu.It
}

Received: November 29, 2011; reviews: 2; accepted: December 22, 2011.

\begin{abstract}
This paper analyses two issues: first, the possibilities for corrections of Lithuanian civil service legal regulation, deliberating on a more flexible regulation perspective. It discusses whether the narrowing of civil service legal regulation could become a potential way to increase the efficiency of public administration with respect to the Lithuanian legal system. It also evaluates the possibilities of discretionary power use in the civil service. Another issue is the possibility of Lithuanian civil servants and public sector employees' statuses change, emphasizing existing problems and alternative considerations that may lead to the correction of the concept of servant in the future. The need for special civil servant status and responsibilities are discussed, as well as the possibilities to extend, narrow or eliminate the corps of civil servants. The paper is based on the data from qualitative research carried out in 2011 in the form of semi-structured interviews with more than fifty of the highest level Lithuanian civil servants, politicians responsible for civil service, and other expertspractitioners of the field.
\end{abstract}




\section{KEYWORDS}

Civil service reform, civil service regulation, civil servant status, civil servant status change, discretionary power 


\section{INTRODUCTION}

An increased concern to improve and modernize public governance results in changes when shaping Lithuanian civil service. The operational programme of the current 15th Government of the Republic of Lithuania emphasized the transformation of state's governance ${ }^{1}$ with a promise to reform the public service in respect to efficiency and cost-effectiveness and to make it more flexible.

Although the means and methods of reforms may vary, determining the relation between legal regulation and public administration, as well as expansion of discretionary powers within the civil services may also be regarded as one of the possible ways to cut the red tape in public administration and to increase its efficiency.

The value of a stable long-term career as a civil servant seems to have become less valued and has given way to a preference for flexibility, innovation, job circulation and an interchange across public and private sectors ${ }^{2}$. The issues of the need for special civil servant status also appear to be become relevant and reasonable in an overall process of public sector reform. It is increasingly acknowledged that the role of civil servants in political-administrative as well as in social systems is becoming less relevant. In his works Christoph Demmke (2004; $2005 ; 2008 ; 2010)$ alludes to a possible death of the civil service. According to the author, differences in functions and employment conditions of civil servants and other public employees become less visible. All of these changes make one wonder about the specific descriptions of civil service status and the need of civil servants in the twenty-first century.

It is therefore interesting to find out how the possibilities to implement the elements of flexibility and efficiency in the form of legal regulation corrections or in the light of status change are evaluated.

In order to more comprehensively discuss such possibilities, qualitative research was carried out in $2011 .^{3}$ More than fifty of Lithuania's highest level civil servants, politicians responsible for civil service and other experts-practitioners of the field were interviewed in the form of a semi-structured interview. ${ }^{4}$

\footnotetext{
1 Penkioliktosios Lietuvos Respublikos Vyriausybès Veiklos Programa (Operational Programme of the 15th Government of the Republic of Lithuania), Supplement to the Resolution of Seimas of the Republic of Lithuania No. XI-52 (December 9, 2008): $3^{\text {rd }}$ part // http://www.Irv.It/bylos/vyriausybes/15_vyr_programa.pdf (accessed November 12, 2011)

2 Jos C.N. Raadschelders, Theo A.J. Toonen, and Frits M. Van der Meer, "Civil Servants in the Enabling Framework State of the 21st Century": 306; in: Jos C.N. Raadschelders, Theo A.J. Toonen and Frits M. Van der Meer, eds., The Civil Service in the 21st Century. Comparative Perspectives (Palgrave: 2007).

3 Under a project entitled "Public Service Reform in the light of Good Governance (Participatory Governance)" (agreement No. MIP - 33/2010).

4 The citations in square brackets in this article refer to those interviews. Those references are not reflected in the bibliographical list in the end as they are not publicly accessible.
} 
This article focuses on two main questions:

1. Whether there is a future perspective for changes in the Lithuanian civil service legal regulation, and whether the correction of legal regulation areas and scope would contribute to a possible increase in its efficiency. The respondents, therefore, were asked to consider whether a detailed regulation of civil service functions would be useful, or maybe only general framework for activities should be established, that would give broader perspectives to implement the elements of flexibility? In this case no strict or specific term of a future perspective was indicated; preliminary focus is on the period of ten years.

2. Another issue to be investigated is the need for defining a specific civil servants status, deliberating on possibilities to unify the statuses of civil servants and public sector employees working under employment contract (to whom the provisions of the Lithuanian Work Code apply). Accordingly, the respondents were asked to debate on the scope of uniform statuses for different groups of civil service employees (civil servants, acting public servants, statutory civil servants and those working under employment contracts) and how they evaluate the possibility to attribute civil servant status only to the statutory officials, while the rest would work under employment contracts?

Therefore, the overall objective of this article is to present the possibilities of civil service legal regulation and the change of civil service statuses in Lithuania.

In order to achieve the objective, the following tasks were defined:

1. To discuss the civil service regulation and its level of detail in the context of traditions and innovation.

2. To evaluate the potential use of discretionary powers within the civil service.

3. To determine whether there is a reasonable background for possible change in civil servants status.

4. To discuss the possibilities of civil servants statuses and corps (extension, narrowing or elimination).

With respect to the key issues presented above, the article contains two sections, with the first focusing on legal regulation and the second on status change prospects. 


\section{POSSIBILITIES OF CHANGE IN CIVIL SERVICE LEGAL REGULATION}

\section{IN LITHUANIA}

Different countries have different attitudes towards the purposes of civil service and the role of the state. ${ }^{5}$ In some countries, detailed regulation is predominant, based on laws and subordinate legislation with detailed description of most civil service elements (recruitment, career, salaries, assessment and other aspects). Others, on the contrary, provide only general principles, thus granting more decision making autonomy to the institutions themselves and thereby securing faster response to the constantly changing environment.

The Lithuanian Law on Civil Service (as of July 1, 2002) provides a quite detailed description of key aspects: posts of civil servants, their rights and obligations, as well as issues of recruitment, career, remuneration, incentive and responsibility, social security, redundancies, training and other. On June 2, 2010, the current Lithuanian Government adopted resolution No. 715 on the Approval on Civil Service Improvement Strategy Concept, where common principles and guidelines for civil service improvement were presented, as well as the measures for implementation of the concept, including the preparation of a draft amendment to the Law on Civil Service of the Republic of Lithuania.

Although this paper does not aim to analyze the provisions of the concept adopted or the draft law drawn up, there are certain interlinkages with the main idea of the paper. One interesting point is the assessment of the possibilities in Lithuania (currently or in the longer term) to implement certain modernization or reform elements not in terms of expanding legal regulation, but through creating general principles and recommendations.

Based on the research data, civil service regulation and its level of detail will be presented in several dimensions, i.e. analysing in the context of traditions and innovation, and the possibilities of discretionary power use.

\subsection{CIVIL SERVICE REGULATION: TRADITION VS. INNOVATION}

Summarizing the research results, it may be stated that:

1) One of the strongest arguments justifying detailed regulation is its connection to political culture. The perception is that different regulation and its level of detail is defined by particular political culture of the country. Central and Eastern European administrative powers and historical development have led to a detailed regulation. Therefore, detailed regulation is as well in line with Lithuanian

\footnotetext{
5 Jurgita Šiugždinienė, "Valstybės tarnybos organizavimas" (Organisation of Public Administration): 76; in: Alvydas Raipa, ed., Ivadas i viešaji valdymą (Kaunas: Technologija, 2009).
} 
legal traditions. However, the question can be raised at this point why Lithuania, after regaining its independence, did not choose to create an open result-oriented civil service based on managerial principles, following the experience of AngloSaxon countries. It was decided to focus on Max Weber and Woodrow Wilson approaches based classical civil service as a functionally homogenous, hierarchical system with powerful bottom-up leadership, which placed significant impact on the development of an overall legislative framework for state's civil service. For example:

The way Central European administrative powers and historical development and perspectives are determines that detailed regulation of public sector is characteristic to this region [State Labour Inspectorate of the Republic of Lithuania, Deputy Chief State Labour Inspector of the Republic of Lithuania, June 20, 2011]; [that] it is directly related to political culture [Ministry of Energy of the Republic of Lithuania, Chancellor, March 9, 2011]; [and] it depends on the country's cultural mentality and historical perspective [Ministry of Finance of the Republic of Lithuania, Budget Department, Director, March 25, 2011].

To justify the argument that this decision might have been made due to a belief that the theory of new public management, originated in the Anglo-Saxon countries, would not be in line with historical and cultural realities of continental European public management.

This idea is also supported within the academic sector. Vainius Smalskys argues that traditional, hierarchical public administration based on vertical, topdown management creates an illusion of security in a society that has no democratic and self-government traditions. ${ }^{6}$ According to Klaus H. Goetz, in the post-communist continental European context, 'modern' public administration was largely synonymous with Weberian public bureaucracy. ${ }^{7}$ Another possible reason is that foreign experts supported Lithuania's idea to implement the classical civil service model. In other words, the most 'suitable' and most popular model within the continental European countries was chosen.

2) Detailed regulation is also associated with Lithuanian historical past and the need for clear demarcation between policy making and administration. 'Knowing the boundaries helps to avoid its misuse'. Respondents assume that:

If the managers of institutions were allowed to set the rules of the game by themselves [with the general framework of Civil Service Law], it would be the most dangerous case, [because] such general framing, allowing to follow

\footnotetext{
6 Vainius Smalskys, "Naujosios viešosios vadybos igyvendinimo problemos kontinentineje Europoje" (Problems of Implementing New Public Management in Continental Europe): 52; Naujoji viešoji vadyba. Mokomoji knyga (Kaunas: Technologija, 2007).

7 Klaus H. Goetz, "Making sense of post-communist central administration: Modernization, Europeanization or Latinization?" Journal of Europeans Public Policy Vol. 8, No. 6 (2001): 1032 - 1033.
} 
general principles only, will not be able to control the progress of civil service and arbitrariness will commence [Ministry of Energy of the Republic of Lithuania, Chancellor, March 9, 2011].

Regulation, therefore, introduces certain procedures. That is to say, a strict hierarchical structure with predefined intermediate procedures in traditional public administration model should restrain the initiatives of certain individuals from turning into arbitrary manifestations beyond the control. ${ }^{8}$ The possibility to interpret certain provisions is considered to be a negative aspect, which may destabilize the system, because "the majority of elements possible to be interpreted more loosely will eventually end up in courts" [Chief Official Ethics Commission, Chairman, June 12 , 2011]. Therefore, the uniform application practice is perceived as a positive feature of the system.

3) Advocating legal traditions is one of the most important things when justifying detailed regulation. Respondents stress the aspect and fact of a legal culture, saying that:

\begin{abstract}
Lawyers have a decisive say, so they write it in detail [Civil Service Department under the Ministry of the Interior, Director, 06 June 2011]; [therefore] the establishment of common principles is possible in theory but not in practice [because] the legal apparatus of the state has been standing on privileges for too long $[\ldots]$ there is case law, coming out of inertia $[\ldots]$ through which the judges state how it is supposed to be. [Despite the fact that] policy shapes certain directions, it is still deeply dependent on lawyers [Chief Official Ethics Commission, Chairman, June 12, 2011].
\end{abstract}

It means that all initiatives to implement innovations must first come through a legal system, which is why often results appear to be different from the initial idea. The initiated changes are eclipsed by the administrative legal management. Civil servants are hindered by strict legal environment which in part restricts the display of initiatives.

One can observe a negative tendency of legislative framework being adjusted before or after the change of governments, which may be regarded as potential incentive for politization, because often election promises are dressed in a legal robe. Into their programmes governments include provisions reforming public administration which are supposed to reduce red tape and to create a more transparent and efficient governance by introducing managerial principles, etc. The initiated changes, however, often pale into insignificance when encountered by administrative legal governance during the reform process. This argument is also supported by $\mathrm{V}$. Smalskys, arguing that continental European reforms of new public

\footnotetext{
8 Aleksandras Patapas, "Tradicinis (hierarchinis) viešasis administravimas" (Traditional (hierarchical)
} Public Administration): 115; in: Viešasis valdymas (Mykolo Romerio universitetas: Vilnius, 2010). 
management face administrative governance influenced by legal positivism. According to him, continental Europe has developed an administrative order conception with only administrative supervision and control functions appointed to governments, and where civil servants are limited by strict legal environment, thus making it difficult to initiate innovations. ${ }^{9}$ Moreover, individual attempts to implement certain managerial elements into the public administration system are less effective than systematic public sector reforms. Strict legal environment sets limits to civil servants' initiative and, historically, German and Austrian schools of public administration have always relied on vertical governance concepts. ${ }^{10}$

4) Cases where courts overrule civil service related decisions, usually on dismissals, issued by authorities are assessed in two ways. On the one hand, an even more detailed regulation is being proposed, in order to avoid interpretation and frequent appeal to courts. On the other hand, it is suggested that institution managers' decisions are rather strictly limited, and by eliminating these decisions the case law is expanded, thus strengthening the regulatory issues.

The respondents emphasized that:

Current legal system is too bulky, too regulatory. A certain borderlines should be defined and more space for implementation should be given, and in doing so creativity would be stimulated. Laws can only establish missions and functions of institutions, while implementation has to be left for institutions' prerogative, because this is how you stimulate creativity and decision making, instead of waiting for high level authorities to make them [...]. Perhaps doing it in the Swedish way where law defines general principles, and peculiarities are agreed in the form of bilateral agreements - it is a very interesting idea, and acceptable to us [Police Department under the Ministry of the Interior, Deputy Police Commissioner General, May 13, 2011].

In so doing, only essential questions would be regulated, while defining the rest of it in the form of recommendations and leaving space to make decisions for institutions themselves, thus affording them greater choice. "Regulation areas should be defined clearly and unambiguously, while elsewhere a certain degree of freedom and certain possibilities to choose options should be given" [State Data Protection Inspectorate, director, September 19, 2011]. With the recommendations provided, managers should make decisions after evaluating the possibility of achieving the anticipated results and maintaining responsibility for the achievement of these results and the activities of institutions themselves. Narrow regulation has a direct link with greater discretion. However, greater responsibility must be set

\footnotetext{
${ }^{9}$ Vainius Smalskys, supra note 6: 39, 41, 48.

${ }_{10}$ Aleksandras Minkevičius and Vainius Smalskys, Valstybės tarnyba užsienio šalyse: raida ir tendencijos (Civil Service in Foreign Countries: trends and development) (Mykolo Romerio universitetas: Vilnius, 2008), p. 22.
} 
accordingly, because "if you give something, you expect responsibility in return" [Government of the Republic of Lithuania, Office of the Prime Minister, Strategic Management Department, Director, March 12, 2011]. This would somewhat help to avoid situations where managers' errors are associated with legal gaps. It is noted that the establishment of a general framework would be more beneficial in terms of procedures and context, because in order to change any element of law it becomes necessary to reregulate the whole system, which results in increased costs of initiated changes (corrections) and greater instability.

It is recognized that detailed regulation slows down the processes of public services; however, legal system, political culture, traditional administration model and strong administrative relations are an essential to ground the need for detailed regulation. Therefore, it is unlikely for certain innovations or managerial principles to be implemented by narrowing legal regulation.

\subsection{DISCRETIONARY POWER OF PUBLIC SERVANTS}

The legal framework will never be comprehensive enough to predict all the possible circumstances affecting certain activities. Thus, there are some situations where discretionary power is exercised in the decision making process. An institution's or official's discretion is a right to decide on an issue, act on their discretion. ${ }^{11}$ Such right of an institution or an official is supposed to facilitate and ensure an efficient performance of functions assigned to the institution, while at the same time contributing to the implementation of human rights and freedoms. The rights granted, however, may have some negative aspects and turn against the person. While officially civil servants have a right to exercise the discretionary power, the question whether this power is being implemented in Lithuania and whether it is worth expanding or whether it must be stringently controlled still remains. It is directly related to how exhaustive the rules in a certain area are.

The respondents unanimously agree that a certain environment for making autonomous decisions shall remain, yet "everything that is not described creates preconditions for misuse" [Ministry of Transport and Communications of the Republic of Lithuania, Vice Minister, March 25, 2011]. This is the point where what is called the 'public morality' begins.

Officially, the concept of administrative discretion establishes various principles determining the limits of exercising discretion. One of the key underlying

11 Birutė Pranevičienè and Algimantas Urmonas, Valstybès tarnautoju diskrecijos teise ir jos igyvendinimo kontrolés kriterijai (Discretionary Power of Civil Servants and Control Criteria for its Implementation): 20; in: Valstybès tarnybos teisinis reguliavimas ir perspektyvos Lietuvos Respublikoje (Vilnius: Lietuvos viešojo administravimo institutas, 2008). 
principles is the rule of law. ${ }^{12}$ However, the research findings show that respondents connect the quality of activity with the human factor. The prevailing opinion is that uncertainty leads to fear, and uncertainty is generally regarded as a negative aspect. "If it is not clearly written then one can look at the provisions more flexibly, however, flexibility creates preconditions for corruption" [National Land Service under the Ministry of Agriculture of the Republic of Lithuania, Senior Expert, September 26, 2011].

The basis of detailed regulation is directly related to the Lithuanian way of thinking, mentality and perception. There still exists a need for clear written rules on how one should act. In other words, due to mentality, arbitrariness and blatant corruption examples the first problem of exercising discretionary power appears: the misuse of powers and trespass of statutory limits for arbitrary purposes: "If an argument that what is not written is not mandatory is characteristics for our society, then there is no point in pretending and saying that we can leave it to selfregulation, for a person himself to decided whether this is ethical or not" [The State Public Health Service under the Ministry of Health, Deputy Director, September 19, 2011]; or, "The adoption of Law on Civil Service in 1999, for example, had a detailed regulation among its goals, without leaving any space for free actions thereby constraining arbitrary activities of a minister" [Ministry of Energy of the Republic of Lithuania, Chancellor, March 9, 2011].

Public servants are afraid to use this right granted to them, therefore they excessively follow procedures.

An institution has no personal opinion, no personal ideas. In every step they just consult a legal act and if there is a gap, than it is bad and $[\ldots]$ then 'ding dong!' $[\cdots]$ Institutions are too used to have it regulated from $A$ to $Z$ and they do not use their own brain [Civil Service Department under the Ministry of the Interior, adviser on public competition to the positions of civil servants, March 12, 2011]; You are so framed into and imposed upon various rules, you have to be careful not to miss something, because otherwise you will be guilty [Republic of Lithuania Ministry of Social Security and Labour, Chancellor, March 17, 2011].

Fear of making decisions results in an even greater procedural way of working.

A somewhat ironic thought has been raised, that "the lower the legal culture there is, the greater regulation it calls for" [Customs Department under the Ministry of Finance of the Republic of Lithuania, Managing Director, June 2, 2011], thus leaving less discretionary power in decision making. It may be related to trust issues, as the fear of making decisions is caused by the fact that negative public

12 Ibid.: 24. 
evaluation is characteristic for Lithuanian civil service. ${ }^{13}$ If the society does not trust the civil service, it means it questions its decisions. In other words, it does not support the wide use of discretionary powers.

Although there is a direct link between the development of discretion and the need for state regulation and efficient public administration, ${ }^{14}$ Lithuania, while trying to avoid problems identified above, experiences the opposite phenomenon. Each action is made stricter and regulated with more detail in order to avoid arbitrary activities; but does this contribute to the efficiency of the system?

From the point of view of safeguarding public interest, if used improperly discretionary powers can turn against a person, as well as detailed regulation can limit an opportunity to help people, that is, to perform the tasks efficiently. Doubts and fear to make decisions are a conscious delay of processes and respective procedures made by officials in an attempt to transfer responsibility to others. Thus the weaknesses of bureaucracy emerge. "Detailed regulation limits self-expression and ability to show initiative" [The State Public Health Service under the Ministry of Health, Deputy Director, September 19, 2011]. A person feels incapable of flexibility, which, in turn, is an unattractive feature of work.

Although traditional public administration emphasizes the value of efficiency and rationality, it has many weaknesses, such as low flexibility, absence of conditions for servants' initiative and the insularity of the system, which do not allow the achieving of an adequate level of efficiency. ${ }^{15}$ In this case, civil servants are no more than implementers of public policy, who have low effect on policy making and little room for action. These features create preconditions for the development of closed-type civil service system with increasing public distrust in civil servants what results in decreasing willingness of citizens to participate in management policy. According to R.B. Denhardt, the concept of administrationpolitics dichotomy is limited to instrumental concerns only, failing to integrate explanation, understanding, critique, control, consensus and communicative elements. ${ }^{16}$ Within this closed static system the civil service is based on strict compliance with rules and functions. Hierarchically organized civil service is suitable for standardized tasks. However, the modern state is transforming into an

\footnotetext{
13 Study on the image of Lithuanian civil service conducted by the public opinion and market research institution "Vilmorus": in 2008, 16\% of Lithuanian citizens gave positive evaluation to the civil service (said that its performance is getting better), $22 \%$ said that civil service performance is getting worse; in $2007,19 \%$ and $13 \%$ respectively. The study was conducted under an order of the Civil Service Department under the Ministry of the Interior (Vilnius: 2008).

${ }^{14}$ Birutè Pranevičienè and Algimantas Urmonas, supra note 11: 24-25.

15 Vladislavas Domarkas, "Naujieji viešojo administravimo raidos akcentai" (Accents of New Public Administration Development), Viešoji politika ir administravimas No. 7 (2004): 8.

${ }^{16}$ Robert B. Denhardt, Viešuju organizaciju teorijos (Theories of Public Organization) (Vilnius: Algarvè, 2001), p. vi.
} 
administrative service provider, and thus flexibility and expert knowledge is becoming more necessary.

In summary, detailed and rather strict regulation today is regarded as a necessary precondition. This is in line with the political culture of the state, traditional administrative model, certain administrative relationships, as well as human factors (abuse, arbitrariness, corruption and etc.). It can be stated that the vast majority advocate detailed regulation but with a perspective to make it more liberal in the future.

As a country we are still too young to be allowed to do what we want [Ministry of the Interior of the Republic of Lithuania, Public Governance Policy Department, Civil Service Policy Division, Head of, April 12, 2011]; we are not quite there, maybe it will take few generations to actually tackle corruption and people at every level will finally realize what is a civil service and what is the civil servant [Government Representative to the County, October 6, 2011]; maybe we are mature enough to just suddenly refuse it (detailed regulation) and at a broad scope [Government of the Republic of Lithuania, Office of the Prime Minister, Strategic Management Department, Director, March 12, 2011].

According to the opinions stated, presently it would be best to develop and promote the use of discretionary power, which would give more flexibility, and would allow making decisions according to specific situation and would contribute to a general objective of efficient public administration. In Lithuania, the exercising of this power is driven rather by fear or ineptitude, trying to transfer the possible decision making outcomes and responsibility to others, which partially influence the insularity of the whole system. Inappropriate use of discretionary power, of course, may result in arbitrariness, citizens may become dependent on the servants' grace, and controversial decisions may appear. However, it is important to understand that the leeway vested with a discretionary power is not absolute. Leeway does not mean there is an opportunity to ignore law or general principles; therefore, the use of this power can be controlled in order to guarantee the appropriateness of discretion. ${ }^{17}$

In summary, it may be stated that the idea that correction of legal regulation areas and scope would contribute to possible increase in efficiency is currently not supported. Therefore, every attempt to modernize the civil service must be assessed in relation to the predominant administrative culture of the rule of law and with the system as a whole. Considering the national culture and traditions, creating special career systems and defining all liabilities with special rules, exceptional working conditions are being created to the civil servants, which should

\footnotetext{
${ }^{17}$ Birutè Pranevičienè and Algimantas Urmonas, supra note 11: 24.
} 
guarantee a lifelong career and protect the civil servant from possible political influence. In this way the status of civil servant becomes exceptional. However, today it can be observed how the possibility of a stable career in the civil service is becoming less appreciated, losing ground to flexibility, which is why the issues of the need for special civil servant status have become an object for debate.

\section{POSSIBILITIES OF CIVIL SERVANT STATUS CHANGE}

In the case of Lithuania, after the restoration of independence an obvious change in the concept of a civil servant can be observed. During the first years of independence, legislations contained different definitions of an official, officer, civil servant and public servant. Labour relations within the then public institutions were based on the Civil Code which also regulated the status of officials. ${ }^{18}$ According to the Law on Officials of the Republic of Lithuania passed in 1995, the professional corps of officials comprised the state governance officials receiving salaries from state or municipal budget. Employees performing economic-technical functions were not considered to be officials. ${ }^{19}$ Adopted in 1999, the Law on Civil Service has expanded the concept of an official, stating that a civil servant is a natural entity who has acquired a statutory status of a civil servant and is performing administrative, economic or technical functions within the public (state or municipal) institutions and providing public services to the society. ${ }^{20}$ This description corresponds to a broad notion of a civil servant. With the new recast adopted in 2002, the definition of a civil servant was again adjusted. The narrowed concept defined civil servant as "a natural entity holding a public office and performing public administration activities"21.

Defining the concept of a civil servant is important to an overall understanding of government apparatus. The public needs to understand what a civil servant is in order to be able to assess the quality of services they provide and to form an adequate opinion on civil servants and civil service system in general. The definitions of a civil servant provided in the three laws show significant change in developing the concept in 1999, when an official was attributed with economic, technical and public service functions, and narrowing it in 2002 by adopting a somewhat limited concept of civil service. Thus, the scope of a law adopted in 2002

\footnotetext{
${ }^{18}$ Aleksandras Minkevičius and Asta Ivanauskienè, "Valstybės tarnybos reforma" (Civil Service Reform): 71 ; in: Kęstutis Masiulis and Algis Krupavičius, Valstybès tarnyba Lietuvoje: praeitis ir dabartis (Vilnius: UAB "Praction", 2007).

19 Lietuvos Respublikos Valdininku istatymas (Law on Officials of the Republic of Lithuania), Official Gazette (1995, no. 33-759) [invalid as of July 30,1999], Articles 3 and 5.

${ }^{20}$ Lietuvos Respublikos Valstybes tarnybos istatymas (Law on Civil Service of the Republic of Lithuania), Official Gazette (1999, no. 66-2130) [amended as of July 1, 2002], Article 2(2).

21 Lietuvos Respublikos Valstybès tarnybos istatymo pakeitimo istatymas (Republic of Lithuania Law Amending the Law on Civil Service), Official Gazette (2002, no. 45-1708), Article 2(2).
} 
has become much more limited, just as it was under the Law on Officials on the Republic of Lithuania. ${ }^{22}$ Such evolutionary change of a concept means that in order to adapt to a constantly changing environment, with the influence of both internal and external factors, Lithuania is trying to find itself the most suitable model. According to the current Law on Civil Service entered passed in 2002, a civil servant is a natural entity, holding a public office and performing public administration activities. ${ }^{23}$

One of the key distinguishing features of a civil servant - serving the public interest - is gradually disappearing. Considerations to integrate economic elements into the public sector by narrowing the borderlines of the public-private relation are increasing. With regard to the latter and the evolutionary change of the Lithuanian civil service concept, the question then is whether the status of civil servants should not be attributed to the statutory personnel, while describing the status of other officers according to the provisions of the Civil Code of the Republic of Lithuania and leaving an overall concept of public sector employees.

\subsection{BACKGROUND FOR STATUS CHANGE}

Civil servants, fully or partially affected by the Law on Civil Service passed in July 2002, are divided into career civil servants, statutory civil servants, civil servants of political (personal) confidence, agency managers and acting public servants. The law also defines the personnel categories to which it does not apply. ${ }^{24}$ Although the Law on Civil Service defines the civil service, civil servant, civil servant status and other basic concepts, as well as the limits and exceptions to law enforcement, in practice, however, confusions appear quite often when deciding whether it is a civil servant or an employee's working under employment contract; that is, what is proportional between the Law on Public Service and the Civil Code of the Republic of Lithuania in one case or another. This was also noted by the Civil Service Department under the Ministry of Interior in its annual report in $2007 .{ }^{25}$ The research data revealed similar problems which provide the basis for new debates and possible changes in the future:

1) The definition and change of the public servant concept creates considerable confusion. It is noted that employees of local authority agencies continue to be called service employees. Another frequently heard definition is

22 Edvardas Žukauskas, "1999-2003 metu Lietuvos valstybės tarnybos pagrindiniai bruožai" (Basic Features of Lithuanian Civil Service in 1999-2003), Valstybès tarnybos aktualijos No.5 (2006): 50.

${ }^{23}$ Republic of Lithuania Law Amending the Law on Civil Service, supra note 21, Article 2(2).

${ }^{24}$ Republic of Lithuania Law Amending the Law on Civil Service, supra note 21, Article $2(5-8,10), 4(5)$.

25 Valstybès tarnybos istatymo ir su juo susijusiu teisès akty taikymo ir igyvendinimo 2007 metais ataskaita (Report on Application and Implementation of the Civil Service Law and Relevant Legal Acts in 2007) (Vilnius: 2008) // http://www.vtd.It/index.php?-2059211288 (accessed November 22, 2011). 
'official'. Both concepts were replaced in 1999 and 2002, respectively, and currently are not legally defined. "There are cases where even activities and status of civil servants and politicians are being confused" [Government Representative to the County, October 6, 2011]. Due to such confusion among the concepts, many negative aspects of public sector and public policy are directly attributed to the civil service. This phenomenon has a negative effect on the image of a civil servant and relatively low public trust.

2) Although the difference between statuses should be distinguished by the given powers and duties, the functions and activities of a civil servant are not completely clear. The reason of this obscurity might be misleading employment relationships when individuals perform identical or similar functions but have different legal status:

In one institution the same position is a civil servant, in another it is an employment contract, while their salaries and other employment conditions are different. So either employment contracts should be removed completely or it has to be clearly stated to what categories employment contracts can be applied [State Data Protection Inspectorate, Director, September 19, 2011].

In state and municipal institutions or agencies a position is attributed to the civil servant position if its description includes functions stated in article 2(1) of the Law on Civil Service. The largest number of positions of civil servants and employees working under employment contracts is determined by the entities referred in the article $8(5)$ of the said law, with no clear distinction between the number of civil servants and the number of employees under employment contracts. In state and municipal institutions or agencies the lists and descriptions of positions are confirmed by the head of institution. Trends in recent years have shown that attributing positions to civil servants or employees working under employment contracts is very relative.

It has also been noted by the experts of the European Union organization Sigma, who recommend making the positions of civil servants and employees more distinct. ${ }^{26}$ The existence of such practice when the functions of civil servants and those working under employment contracts overlap is associated with the illtreatment and failure to comply with the statutory provisions. In other words, institutions themselves do not provide a clear distribution of functions and activities:

\footnotetext{
${ }^{26}$ Jan-Hinrik Meyer-Sahling and Vitalis Nakrošis, "Lietuvos valstybès tarnyba ir jos modernizavimo gairès (santrauka)" (Lithuanian Civil Service and Guidelines for its Modernization (Abstract)), International Conference, Vilnius, February 2009 // http://www.vtd.It/index.php?-1086560843 (accessed November 19, 2011).
} 
Those who actually work under employment contracts should in theory be assigned with different tasks, and if this is not the case, then, in my opinion, is only an issue of non compliance with current legal framework [Republic of Lithuania Ministry of the Interior, Public Governance Policy Department, Local Government Policy Division, Head of, 12 April 2011]. Not all the institutions have the same understanding and not all of them divide these positions as they should be divided - these are employees, and these are civil servants. So this might be a problem of institutions, and their incapacity to exercise the law properly [Republic of Lithuania Ministry of the Interior, Personnel Division, Acting Director, July 13, 2011].

3) It is becoming common practice to recruit more employees under ordinary employment contracts and thus to artificially reduce the number of civil servants in order to save institutional money.

In order to save money, heads of institutions try to make ultimate cuts in the number of civil servants, which are sometimes artificial. This leads to an increased number of staff working under employment contracts. This thing in Lithuania acquires certain grimaces. And in certain situations and institutions, two persons doing similar work, one is an officer, and another is not [Seimas of the Republic of Lithuania, Committee on State Administration and Local Authorities, adviser, May 19, 2011].

The fact that attributing positions to civil servants or employees working under employment contracts is often dependent on the wages fund of an institution is also supported by the 2007 annual report of the Civil Service Department under the Ministry of the Interior. ${ }^{27}$ This can somewhat explain why employees with different statuses perform similar functions. On the other hand, however, this leads to a greater number of employees recruited under employment contracts, which results in assimilation of functions performed, and causes inner tension and frustration. According to the Register of Civil Servants data of November 4, 2011, the number of positions held by civil servants (excluding the statutory ones) is 27 531 , and the number of those working under employment contracts is $20663 .{ }^{28}$ In cases where identical functions are performed by employees with different statuses can also be found in other European countries, because, according to Christoph Demmke, in some European countries civil servants and employees under employment contracts are employed to hold the same office. ${ }^{29}$

\footnotetext{
27 Report on Application and Implementation of the Civil Service Law and Relevant Legal Acts in 2007, supra note 25, p. 10.

${ }_{28}$ Positions of Civil Servants and Other Employees, Civil Service Department under the Ministry of the Interior // http://www.vtd.It/index.php?-510024592 (accessed November 28, 2011).

${ }_{29}$ Christoph Demmke, Are Civil Servants Different because They Are Civil Servants? (Luxembourg: EIPA, 2005).
} 
4) There exist informal probationary periods, using the status of acting public servants or employment contracts. According to the Law on Civil Service of the Republic of Lithuania, an acting public servant is a public servant, recruited to the office of a career civil servant, until a career civil servant will be recruited to this office in accordance with the procedure prescribed by this Law, also a civil servant, substituting for a career public servant or civil servant of political (personal) confidence temporarily unable to perform his duties. ${ }^{30}$

I can say that such practice exists or it is a justified practice. The Law on Civil Service is not always useful for the institution itself. Currently, when you recruit a civil servant, it is very complicated to fire him. $[\cdots]$ there is no probationary period. Also, there is no possibility to make a fixed-term employment contract. As an in between option, lets say, we can test employees or recruit him as an acting servant, and then you announce a vacancy, and if he wins, he wins. Or you can employ him under employment contract and you watch then, test him, see how he is, and so you make like a probationary period, an informal one. Anyway, all this could be stated in the Law on Civil Service itself [National Audit Office of Lithuania, Deputy Auditor General, June 16, 2011].

In other words, when there is fear of a career civil servant who may not fulfil the expectations, institutions look for legal loopholes and create artificial probationary periods. This argument is to some extent supported by the change made in recruitment conditions for acting civil servants. The law adopted in 2002 provides changes in recruitment conditions for acting public servants, establishing a mandatory announcement of competition. However, already in 2005 the prior procedure was restored, allowing the recruitment of acting public servants without special competition. ${ }^{31}$ The issue of acting public servants was also highlighted by the experts of Sigma, a European Union organization, who recommended selecting acting public servants in the form simple competition. ${ }^{32}$

In order to avoid artificial probationary periods, according to the research data, a consensus to officially regulate certain aspects appears, for example:

1. Application of reverse process: to select acting public servants in the form of competition, and, having set a certain length of service in a acting position, to give employees of this status an advantage to become permanent career civil servants when there is a vacancy. This would ensure the recruitment

\footnotetext{
${ }^{30}$ Republic of Lithuania Law Amending the Law on Civil Service, supra note 21, Article 2(10).

31 Lietuvos Respublikos Valstybès tarnybos istatymo 2, 4, 6, 9, 10, 11, 13, 14, 15, 16, 17, 18, 19, 21, 22, 24, 27, 30, 34, 35, 36, 39, 40, 41, 42, 43, 44, 45, 49, 50 straipsniu pakeitimo ir papildymo bei istatymo papildymo 16(1) ir 31(1) straipsniais istatymas (Law on the Amendments to the Articles and Amendments and Supplements to the Appendix of the Law on Civil Service and Supplemental Articles to the Law of the Republic of Lithuania), Official Gazette (2006, no. 4-97).

32 Jan-Hinrik Meyer-Sahling and Vitalis Nakrošis, supra note 26.
} 
competitiveness and would enable to maintain a person with good evaluation and seniority.

\begin{abstract}
A possibility to employ a person without a competition, who has been working as an acting public servant with the institution for, say, more than three years, would be welcomed. If he really has good evaluation, then he can hold no higher position than that he had as an acting employee, and then we find a spot for him and employ him. As far as I know, not all the institutions play such games [Ministry of Environment of the Republic of Lithuania, Chancellor of the Ministry, March 28, 2011].
\end{abstract}

2. Respondents propose another idea, that acting public servants could be employed under employment contracts. Currently, an acting public servant is bound to meet the same criteria as career civil servants. For example, if the latter must have had three years of seniority or specific education, an acting public servant is also bound to comply with these special requirements. Thus, problems appear when an acting public servant is needed urgently. Although it would become simpler and more flexible to employ an acting public servant under employment contract, certain obscurity might arise; however, as to why the same position is attributed to public administration activities that have special requirements and a competition to be organized, while in other cases (during the acting period) the same functions could be performed by a person working under employment contract. As was mentioned previously, the dividing line between functions and activities of civil servants and persons employed within the same institution under employment contracts is very narrow, and often crossed. Therefore, employment of acting public servants under employment contracts would eliminate the distinctiveness of a civil servant status and their exclusive performance of administrative functions.

3. An idea is being raised to make a formal mandatory probationary period for senior officials by connecting it to periodic training system. During the period set, which could be divided into several stages, a person would have to participate in certain training courses and receive certain certificates, which would enable him to become a permanent civil servant.

4. Despite the fact that respondents were not determined to comment on the status of temporary public servant, which was attempted to be introduced in the new project of the Law on Civil Service and would replace the current acting public servant definition as follows: "a civil servant substituting for a career civil servant or civil servant of political (personal) confidence temporarily unable to perform his duties, a civil servant recruited into career civil servant position during a 
competition period, also a civil servant recruited to perform temporary functions" ${ }^{\prime 33}$, there is no doubt that the possibility to employ temporary officials to perform temporary functions, leaving a very vague notion that "into temporary open civil service positions a person may as well be employed without a competition for other reasons ${ }^{\prime 34}$, will raise reasonable debates as to why institutions would not employ temporary employees to perform temporary functions under employment contracts. "Temporary employees would have high qualification and receive good salary, but they would not have all rights and guarantees. They would not cause tension, because career civil servants would realize they are not permanent" [Seimas of the Republic of Lithuania, Committee on Legal Affairs, Chairman, June 29, 2011].

The conclusion may follow that present problems and considerations for options may lead to a correction of the civil service concept. Therefore, debates on this issue are valid and reasonable.

\subsection{STATUS UNIFICATION POSSIBILITIES: PROS AND CONS}

As an institution the civil service is expected to be professional and competent, providing impartial information. According to Jos C.N. Raadschelders et al., "internal recruitment, promotion based on seniority, and the value of a stable long-term career as a civil servant seems to have become less valued and has given way to a preference for flexibility, innovation, job circulation and an interchange across public and private sectors." ${ }^{35}$ Fascination with the faceless bureaucrat as a valuable employee is fading. Based on the research data, the article aims to identify the major prospects to unify the statuses of civil servants and public sector employees working under employment contracts.

\subsubsection{THE IMPORTANCE OF SPECIAL STATUS}

The importance of special status is estimated in two ways. On the one hand, an exceptional status implies particular privileges, greater responsibility and is regarded as an incentive:

Civil servant is a special person. He must know more, he must perform better, he must have excellent education, he must have good salary, reputation, and set of values. It must me an honour to become one and this status has to be

\footnotetext{
${ }^{33}$ Lietuvos Respublikos Valstybès tarnybos istatymo pakeitimo istatymo projektas (Project of the Law Amending the Law on Civil Service of the Republic of Lithuania), No. 10-4358-02 // http://www.Irs.It/pls/proj/dokpaieska.showdoc_l?p_id=73709\&p_org=\&p_fix=y\&p_gov=n (accessed November 28, 2011).

${ }^{34}$ Ibid.

35 Jos C.N. Raadschelders, Theo A.J. Toonen, and Frits M. Van der Meer, supra note 2, p. 306.
} 
actually very important [Government Representative to the County, October 6, 2011].

A civil servant is a special entity with respective administrative legal status, meaning that his legal relationship with a state and other legal entities is specific. Public institution or agency and his official are bonded with subordinate relationship. The emergence of this relationship is based on administrative act, not on employment contract. In other words, a civil servant is supposed create a higher added value as opposed to an employee with employment contract. The question, however, is whether it can be done in practice. Vanishing boundaries between the functions performed by public servants and employees with employment contracts create mutual tension. Because of this fact, the position of civil servant as a guardian of public interest gradually fades away, yet the responsibility remains, and the motion to make them equal with employees working under employment contracts results in resentment, as social guarantees and salaries of the latter are lower.

An obvious difference appears when comparing data of individual institutions on average wage of civil servants and persons working under employment contracts. Such data is publicly available. For example, a civil servant (senior specialist) at the Lithuanian Ministry of the Interior in 2011 third quarter received an average monthly wage of LTL 3069 before taxes (salary, seniority bonuses and qualification level), while an average monthly wage of a senior specialist working under employment contract is LTL 2420 before taxes (salary, bonuses, premiums and single payments). ${ }^{36}$ Respectively, Lithuanian Ministry of Energy data of 2011 third quarter show that its civil servants (heads of unit) receive an average monthly wage of LTL 5264, while heads of unit with employment contracts receive an average monthly wage of LTL $2647 .{ }^{37}$ In other words, those working under employment contracts receive lower salaries than civil servants.

However, the importance of a special status must be realized by the servants themselves in order to protect this status of becoming nothing more than "a synonym of a guaranteed income" [Ministry of the Interior of the Republic of Lithuania, Public Governance Policy Department, Head of Local Government Policy Division, April 12, 2011]. In such case, some negative status related aspects can be identified. Acquiring the status of a servant is seen as a natural achievement of a result (especially in cases where a person has previously had employment

\footnotetext{
${ }^{36}$ Darbo užmokestis, Ministry of the Interior of the Republic of Lithuania // http://www.vrm.It/index.php?id=1164 (accessed November 28, 2011).

37 Informacija apie darbo užmokesi, Ministry of Energy of the Republic of Lithuania // http://www.enmin.It/It/activity/du/ (accessed November 28, 2011).
} 
contract), not motivating to endeavour and improve further and enabling to 'relax' and feel protected from possible dismissal by the civil service law.

Both from my personal experience and from what I have heard, those with employment contrasts sign these contracts, but the first objective and I mean strategic objective is to switch to the civil service. This means that while he works under this agreement, he sort of has motivation to endeavour, to move forward somehow. And it seems that when he finally achieves this public service position, he can somewhat relax, because, you see, now this civil service law is protecting him, and he knows now that he will have these guarantees as well [The Association of Local Authorities in Lithuania, Representative, June 8, 2011].

The respondents have shared real life situations when individuals with employment contracts develop a key strategic goal to switch to the civil service. They have also noted that their internal surveys reflect the same tendency: "individuals with employment contracts, they want to become civil servants" [National Paying Agency under the Ministry of Agriculture, Acting Director, October 6, 2010]. Aiming to achieve certain objective works as an incentive to make an effort.

The question can thus be raised whether a public function performed by the state is in some way more valuable than work carried out by the private sector, and, if so, should the public sector be given greater value than the private. According to Christopher Demmke, "when the state ceases to be above society and stands alongside it, a special relationship between public servants and the state seems superfluous, ${ }^{\prime 38}$ and in such case the need for special legal status is withdrawn. Moreover, it is quite difficult to prove why in some countries, for example, teachers should have an exceptional status of civil servant, while in others they can perfectly handle their duties without having any special status.

On the one hand, it may be concluded that a special status is necessary because it is designed to perform special functions and is regarded as an incentive. On the other hand, if there are specific tasks to be carried out it does not necessarily mean that they require special legal status. For example, specific points may be easily indicated in a simple employment contract.

\subsubsection{ISSUES OF RESPONSIBILITY}

Deliberating on possible changes in civil servant status, the importance of responsibility is given a special emphasis, stressing that tasks requiring

${ }^{38}$ Christoph Demmke and Timo Moilanen, Civil Services in the EU of 27 Reform Outcomes and the Future of the Civil Service (Peter Lang: 2010), p. 227. 
responsibility may not be compared to the routine technical duties that demand virtually no responsibility.

If compared to career civil servants, those who work under employment contracts have different responsibilities, and the nature of their functions is different, their responsibilities and powers are limited when it comes to administrative decision making, thus, status differentiation as such is unnecessary [National Land Service under the Ministry of Agriculture of the Republic of Lithuania, September 26, 2011].

If a person represents a state and if he is given certain guarantees, then his responsibility should also be much stricter [Ministry of the Interior of the Republic of Lithuania, Public Governance Policy Department, Head of Local Government Policy Division, April 12, 2011].

Civil servants, acting as intermediates between the public and political authorities, have freedom of administrative action in implementing public policy. Therefore, they should be subjected to higher standards of conduct and required a greater responsibility. Responsibility is associated with freedom of action. It shows that civil servants are regarded as public policy entities, which endows them with a certain power. It is believed that those working under an employment contract have limited responsibilities and powers in comparison to career civil servants, as the latter have the power to make administrative decisions.

Evaluating employees with employment contracts, the respondents placed greater emphasis not on responsibility, but on limitation. The dominating opinion was that employees with employment contracts should carry out technical, auxiliary and supportive functions that are not related to decision making processes. They should be an auxiliary staff not directly involved in state governance and policy making.

However, focusing exceptionally on the status (employment) granting and the level of responsibility, the question may be raised whether a civil servant, working under employment contract and performing the same functions, will lose a sense of responsibility? Will it change? Although such considerations require more comprehensive empirical research, for the moment, however, there is no evidence that civil servants work in a more responsible manner than public sector employees.

Interestingly, the prevailing view is that with the more flexible labour relations system and a greater number of employees with employment contracts, it becomes possible for greater abuse to occur. In other words, the special status of a civil servant to some extent 'raises the limit of responsibility' that is thought to grant greater moral responsibility. 


\subsubsection{POSSIBILITIES FOR STATUS CHANGE}

\section{Extension?}

In order to eliminate the tension between institutional employees with different status, what may be considered is extending the range of civil service employees, going back, for example, to the 1999s regulation when a civil servant was considered to be an individual performing administrative, economic and technical functions and providing public services to the society. ${ }^{39}$ There were some considerations, however, that all public sector employees receiving their salary from the budget (excluding the statutory ones) should be co-regulated. It can be noted that this idea is poorly supported, as consideration of status unification or expansion possibilities is directly related to financial issues, notably the salary. Statements were expressed that, in principle, "there should be public servants, yet now they are 'tucked under employment contract' due to limited financial possibilities" [Seimas of the Republic of Lithuania, Committee on Legal Affairs, Chairman, June 29, 2011].

Currently, there are slightly more than 27000 civil servants, excluding the statutory ones, in Lithuania (data of October 2011). ${ }^{40}$ During the recent decade controversial trends have emerged and the problems of civil servant surplus and overlapping functions were stressed. Programmes of former governments suggest that it is important "to give more detail to functions of every state and municipal institution and to eliminate the overlapping", "with the establishment of a new one or reorganization of a current institution an overall number of civil servants within an institution should not be increased," 41 "to carry out performance audit across government institutions and to optimize their management in accordance with the results obtained." ${ }^{\prime 22}$ The current Government elected in 2008 has not only foreseen in its programme the provisions of reduction in wages, but also of achieving optimal management. Many other provisions are directly related to economic hardship. One can think in this connection of Wagner's law, which says that the more economically stronger the state is the larger public sector it has. ${ }^{43}$ Hence, it would appear that

\footnotetext{
39 Law on Civil Service of the Republic of Lithuania [amended as of July 1, 2002], supra note 20, Article 2(2).

${ }^{40}$ Number of the Civil Servants, Civil Service Department under the Ministry of the Interior // http://www.vtd.It/index.php?1471208505 (accessed November 9, 2011).

${ }^{41}$ Lietuvos Respublikos Vyriausybès 2000-2004 programa (2000-2004 Programme of the Government of the Republic of Lithuania), p. 7-8 //

http://www.Irv.It/bylos/vyriausybes/po_1990_11_programa.pdf (accessed November 13, 2011).

42 Lietuvos Respublikos Vyriausybes 2001-2004 programa (2000-2004 Programme of the Government of the Republic of Lithuania), p. 25 //

http://www.Irv.It/bylos/vyriausybes/12-vyr-dok/12-programa.pdf (accessed November 13, 2011).

${ }^{43}$ Algis Krupavičius, "Politikos ir valstybès tarnybos saveika" (The Interaction of Policy and Civil Service): 307; in: Kęstutis Masiulis and Algis Krupavičius, Valstybès tarnyba Lietuvoje: praeitis ir dabartis, (Vilnius: UAB "Praction", 2007).
} 
the broadening of the notion of civil service is not likely to become a Lithuanian civil service policy direction in the near future.

\section{Narrowing?}

The research data showed that the idea to narrow the corps of civil servants and to make a clearer definition of the concept of a civil servant is welcomed.

Currently the concept of a civil servant very platitudinous and of course it needs to be narrowed. There should not be such an army of civil servants, it is too big. Of course we need to see who have the decision making power. I would agree to the narrowing. The title itself would be beneficial, including the guarantees it offers. Narrowing is probably a way forward [Lithuanian Labour Exchange under the Ministry of Social Security and Labour, Deputy Director, July 15, 2011].

In so doing, the nature of civil service would be identified more clearly, granting to civil servants an exceptional security and prestige based status.

The prevailing opinion is that a different status should still exist, but it is very important to purify their functions and to identify the corps of civil servants and duties thereto as clearly as possible. And if there is an inadequate distribution of work within the institution, then it is a matter of legislative failure.

The official declaration of the Government to optimize the overall management to some extent supports the existence of civil servants as a narrower, yet more exceptional corps.

\section{Elimination?}

Respondents were asked to deliberate on the possibility of an overall elimination of a career-based system, while employing all the civil servants (excluding the statutory ones) under bilateral agreements, which can be terminated at any time by any party. Thus, the status and role of public sector employees would practically be the same as that of the ordinary private sector employees.

Respondents expressed concern that in Europe it is rather uncommon to eliminate the status of civil servants. It is feared that in that case "we would not have a traditional classical civil service and Lithuania is not fairytale country, it is in the European Union" [Government Representative to the County, October 6, 2011]; thus, it is hard to predict if such cardinal changes of the system would serve their full purpose. In other words, it is not common in Lithuania to implement principles that are not practiced in other EU Member States.

The necessity for continuity and stability was also stressed, thereby indicating certain threats, in case career opportunities will not be guaranteed and civil servants will be employed under employment contracts, it can quickly lead to the 
loss of institutional memory and accessibility. Although regulation of labour relationships through contracts could lead to greater efficiency, individual remuneration system and enhanced motivation, it may as well lead to decreasing loyalty, conflicts of interest, political instability, etc. The fact that no reform brings only positive results should be considered. Indeed, most of them simultaneously create new challenges.

\section{CONCLUSIONS AND RECOMMENDATIONS}

1. Detailed legal regulation is characteristic of Lithuanian civil service. This is determined by legal environment, a traditional administrative model, specific administrative relationships and the political culture. Therefore, various initiatives and attempts to implement managerial principles have to go through the legal system, administrative legal governance, traditions and thus are often eclipsed by the process itself. The research showed that it is very unlikely for novelties to be implemented through narrowing legal regulation.

2. The research showed that in Lithuania discretionary power is not being used properly. Servants are afraid to make autonomous decisions, and often try to transfer the decision making right to a higher level, thus avoiding responsibility. This results in stalled decision making, procedural delay, the absence of initiative and the insularity of the system in general.

3. The respondents identified a number of problems (e.g. inaccurate definitions of concepts and difference between civil servants and other employees' functions; informal probationary periods by using acting public servant status or employment contracts positions) which show that reasonable assumptions for possible civil status change in the future do exist.

4. The research showed that the possibility to officially unify status regulation is rejected. Moreover, the possibility to attribute civil service status exceptionally to statutory servants is assessed rather casually. That is to say, the need to retain a separate civil service segment is still present, while attempts to implement new elements are likely to appear only if changing the status of acting public servants or introducing the status of temporary public servants.

\section{Recommendations are:}

5. To develop and promote the appropriate use of discretionary power, which endows flexibility that would enable rational and reasoned decision making depending on certain situation and would contribute to the affiance of civil service at large. In so doing, a faster decision making process would be guaranteed and a deliberate transfer of responsibility would be avoided. 
6. To recruit acting public servants on the basis of competition, to establish certain seniority level for acting servant post and to give priority to such status holders to become permanent career civil servants when an open post occurs. This would ensure a competition for being recruited and would present an opportunity to retain an individual with good evaluation and seniority.

7. To define more accurately what a career civil servant is and how he differs from other employees; to lessen the corps of civil servants and to assign the maximum individual numbers of civil servants and employees under employment contracts within the institutions.

\section{BIBLIOGRAPHY}

1. Darbo užmokestis. Ministry of the Interior of the Republic of Lithuania // http://www.vrm.It/index.php?id=1164 (accessed November 28, 2011).

2. Demmke, Christoph, and Timo Moilanen. Civil Services in the EU of 27 Reform Outcomes and the Future of the Civil Service. Peter Lang: 2010.

3. Demmke, Christoph. Are Civil Servants Different because They Are Civil Servants? Luxembourg: EIPA, 2005.

4. Denhardt, Robert B. Viešuju organizaciju teorijos (Theories of Public Organization). Vilnius: Algarvè, 2001.

5. Domarkas, Vladislavas. "Naujieji viešojo administravimo raidos akcentai" (Accents of New Public Administration Development). Viešoji politika ir administravimas No. 7 (2004): 7-15.

6. Goetz, K.H. "Making sense of post-communist central administration: Modernization, Europeanization or Latinization?" Journal of Europeans Public Policy Vol. 8, No. 6 (2001): 1032-1051.

7. Informacija apie darbo užmokesti. Ministry of Energy of the Republic of Lithuania //

http://www.enmin.It/lt/activity/du/ (accessed November 28, 2011).

8. Krupavičius, Algis. "Politikos ir valstybès tarnybos saveika" (The Interaction of Policy and Civil Service): 305-341. In: Kęstutis Masiulis and Algis Krupavičius, eds. Valstybès tarnyba Lietuvoje: praeitis ir dabartis. Vilnius: UAB "Praction", 2007.

9. Meyer-Sahling, Jan-Hinrik, and Nakrošis Vitalis. "Lietuvos valstybès tarnyba ir jos modernizavimo gairès (santrauka)" (Lithuanian Civil Service and Guidelines for its Modernization (Abstract)). International Conference. Vilnius, February 2009 // http://www.vtd.It/index.php?-1086560843 (accessed November 19, 2011). 
10. Minkevičius, Aleksandras, and Asta Ivanauskienè. "Valstybès tarnybos reforma" (Civil Service Reform): 58-96. In: Kęstutis Masiulis and Algis Krupavičius, eds. Valstybès tarnyba Lietuvoje: praeitis ir dabartis. Vilnius: UAB "Praction", 2007.

11. Minkevičius, Aleksandras, and Vainius Smalskys. Valstybės tarnyba užsienio šalyse: raida ir tendencijos (Civil Service in Foreign Countries: Trends and Development). Mykolo Romerio universitetas: Vilnius, 2008.

12. Number of the Civil Servants. Civil Service Department Under the Ministry of the Interior // http://www.vtd.It/index.php?1471208505 (accessed November 9, 2011).

13. Patapas, Aleksandras. "Tradicinis (hierarchinis) viešasis administravimas" (Traditional (Hierarchical) Public Administration): 108-122. In: Viešasis valdymas. Mykolo Romerio universitetas: Vilnius, 2010.

14. Positions of Civil Servants and Other Employees. Civil Service Department Under the Ministry of the Interior //

http://www.vtd.It/index.php?-510024592 (accessed November 28, 2011).

15. Pranevičienè, Birutè, and Algimantas Urmonas. "Valstybès tarnautoju diskrecijos teisè ir jos igyvendinimo kontrolès kriterijai" (Discretionary Power of Civil Servants and Control Criteria for its Implementation): 20-29. In: Valstybess tarnybos teisinis reguliavimas ir perspektyvos Lietuvos Respublikoje. Vilnius: Lietuvos viešojo administravimo institutas, 2008.

16. Raadschelders, Jos C.N., Theo A.J. Toonen, and Frits M. Van der Meer. "Civil Servants in the Enabling Framework State of the 21st Century": 299-315. In: Jos C.N. Raadschelders, Theo A.J. Toonen and Frits M. Van der Meer, eds. The Civil Service in the 21st Century. Comparative Perspectives. Palgrave: 2007.

17. Smalskys, Vainius. "Naujosios viešosios vadybos igyvendinimo problemos kontinentinejje Europoje" (Problems of Implementing New Public Management in Continental Europe): 39-56. In: Naujoji viešoji vadyba. Mokomoji knyga. Kaunas: Technologija, 2007.

18. Šiugždinienè, Jurgita. "Valstybès tarnybos organizavimas" (Organisation of Public Administration): 70-77. In: Alvydas Raipa, ed. Ivadas $i$ viešaji valdymą (Kaunas: Technologija, 2009).

19. Žukauskas, Edvardas. "1999-2003 metu Lietuvos valstybès tarnybos pagrindiniai bruožai" (Basic Features of Lithuanian Civil Service in 19992003). Valstybès tarnybos aktualijos No. 5 (2006): 48-50. 


\section{LEGAL REFERENCES}

1. Lietuvos Respublikos Valdininku istatymas (Law on Officials of the Republic of Lithuania). Official Gazette, 1995, no. 33-759 [invalid as of July 30, 1999].

2. Lietuvos Respublikos Valstybès tarnybos istatymas (Law on Civil Service of the Republic of Lithuania). Official Gazette, 1999, no. 66-2130 [amended as of July 1 , 2002].

3. Lietuvos Respublikos Valstybès tarnybos istatymo pakeitimo istatymas (Republic of Lithuania Law Amending the Law on Civil Service). Official Gazette, 2002, no. 45-1708.

4. Lietuvos Respublikos Valstybès tarnybos istatymo 2, 4, 6, 9, 10, 11, 13, 14, $15,16,17,18,19,21,22,24,27,30,34,35,36,39,40,41,42,43,44,45$, 49, 50 straipsniu pakeitimo ir papildymo bei istatymo papildymo 16(1) ir 31(1) straipsniais istatymas (Law on the Amendments to the Articles and Amendments and Supplements to the Appendix of the Law on Civil Service and Supplemental Articles to the Law of the Republic of Lithuania). Official Gazette, 2006, no. 4-97.

5. Lietuvos Respublikos Valstybès tarnybos istatymo pakeitimo istatymo projektas (Project of the Law Amending the Law on Civil Service of the Republic of Lithuania). No. 10-4358-02 //

http://www.Irs.It/pls/proj/dokpaieska.showdoc_l?p_id=73709\&p_org=\&p_fix= y\&p_gov=n (accessed November 28, 2011).

6. Lietuvos Respublikos Vyriausybès 2000-2004 programa (2000-2004 Programme of the Government of the Republic of Lithuania) // http://www.Irv.It/bylos/vyriausybes/po_1990_11_programa.pdf (accessed November 13, 2011).

7. Lietuvos Respublikos Vyriausybès 2001-2004 programa (2000-2004 Programme of the Government of the Republic of Lithuania) // http://www.Irv.It/bylos/vyriausybes/12-vyr-dok/12-programa.pdf (accessed November 13, 2011).

8. Penkioliktosios Lietuvos Respublikos Vyriausybès Veiklos Programa (Operational Programme of the 15th Government of the Republic of Lithuania). Supplement to the Resolution of Seimas of the Republic of Lithuania No. XI-52 (December 9, 2008) //

http://www.Irv.It/bylos/vyriausybes/15_vyr_programa.pdf (accessed November 12, 2011).

9. Valstybejs tarnybos istatymo ir su juo susijusiu teisès aktu taikymo ir igyvendinimo 2007 metais ataskaita (Report on Application and 
Implementation of the Civil Service Law and Relevant Legal Acts in 2007). Vilnius: $2008 / /$

http://www.vtd.It/index.php?-2059211288 (accessed November 22, 2011). 